\title{
Reconnaissance Bedrock Geologic Map of the \\ Marlborough Quadrangle, Massachusetts
}

\author{
by
}

Patrick J. Barosh

U.S. Geological Survey Open File Report 7ㅇ-221

Note: We call the readers attention to the existence of an alternate interpretation of the Geology of the Marlborough quadrangle, available as -- Hepburn, C. J., and Di Nitlo, R. G. Preliminary bedrock geologic map of the Marlborough quadrangle, Middlesex and Worcester Counties, Massachusetts: U.S. Geological Survey Open File Report 78-222 
Marlborough Quadrangle, Barosh

\section{DESCRIPTION OF MAP UNITS}

\section{Igneous Rocks}

qd

Quartz Diorite, light- to medium-grey, weathering same to slightly darker, fine-grained equagranular rock approximately quartz diorite in composition with fine biotite forming 3 to 10 percent and minor hornblende. The rock is non-foliated to slightly foliated. It cuts the biotite quartz diorite and appears to cut the granodiorite also. The quartz diorite occurs as small bodies, dikes and sills in the Marlboro Formation and in the areas of granodiorite and biotite quartz diorite.

$$
\text { gd }
$$

Granodiorite, light pinkish gray, weathering slightly darker with brown or rusty cast, fine- to medium-grained, equagranular to seriate non foliated to slightly folia ted rock approximately granodiorite in composition. The mafic minerals consist mainly of small scattered biotite flakes with minor amount of magnetite. The feldspars are usually salmon pink, some of the coloring may be due to a slight alteration. The foliation is probably primary. The rock contains many xenoliths of biotite quartz diorlte and scattered small bodies of quartz diorite that are not mapped separately. 
Andover Granite, light- to medium-gray, weathering slightly darker with a rusty cast, slightly- to well-foliated, mostly medium-coarse to coarse-grained equigranular quartz monzonite in which quartz, plagioclase, and potassium feldspars occur in nearly equal proportions and constitute 85 to 95 percent of most specimens. Mica ranges from about 3 to 12 percent with biotite exceeding muscovite at most localities. Simple granitic pegmatite bodies, both conformable and cross-cutting to the foliation are very common in this rock. The Andover contains numerous xenoliths and scattered pendents of the undivided Nashoba Formation, that are not mapped separately. These are considered to be mainly Shawsheen Gneiss by D. C. Alvord (personal commun.).

The Andover Granite intrudes the Nashoba Formation and associated metamorphosed stratified rocks that lie between the Clinton-Newbury and Bloody Bluff fault zone. The stratigraphic position of these rocks is not known, but regional considerations suggest that they vary from Precambrian to Early Paleozoic. According to Zartman (1976, personal commun.) the best radiometric date for the Andover at the present time is a $\mathrm{Rb} / \mathrm{Sr}$ whole rock date of $460 \pm \mathrm{my}$, Late Ordovician. 
agd

Assabet Quartz Diorite, medium- to dark-gray medium grained slightly to moderately foliated quartz diorite composed of andesine, hornblende, quartz and biotite; it contains considerable accessory apatite and some sphene and hematite according to Hansen (1956). The Straw Hollow Diorite of Hansen (1956), which is exposed near the southern border of the Hudson quadrangle extending southwestward into the Marlborough quadrangle, is lumped with the Assabet for this map. This diorite is mostly medium-grained, medium-gray, composed of andesine, hornblende, biotite, and minor amounts of apatite and sulfides and veinlets of quartz. According to K. G. Bell (personal commun.) the Assabet and Straw Hollow are mafic equivalents of the Andover. The Assabet cuts rocks of the Nashoba Formation. No radiometric dates have been obtained from the Assabet.

\section{bqd}

Biotite Quartz Diorite, medium-gray, weathering slightly darker with a brownish cast, medium-grained equagranular rock, approximately biotite quartz diorite in composition. Mafic minerals consist of 10 to 15 percent biotite and 5 to 10 percent hornblende. The rock varies from non- to strongly foliated, but is generally moderately foliated. The rock occurs as abundant scattered xenoliths in the granodiorite and generally cannot be mapped separately. The rock is cut by the quartz diorite and granodiorite at all angles to the foliation. Adjacent xenoliths commonly have different attitudes of the foliation and appear to form an intrusive breccia rather than parts of folded rock that was intruded. 
wqd

Wolfpen Quartz Diorite, slightly mottled light gray, light pinkish gray, medium-gray and medium greenish gray, weathering darker generally with a brownish cast, fine-grained grading to very finegrained hornfelsic rock of approximately quartz diorite in composition. The rock appears to be propylitised as mafics are altered to chlorite, much of the feldspar is altered to light gray or pink and the grain boundaries are very indistinct. The rock is highly sheared locally, but does not appear to be foliated. The rock may represent a local altered late contact phase of the Salem gabbro-diorite or possibly even of the quartz monzonite-granodiorite unit. A few quartzite xenoliths are present. The rock was described by Emerson (1917, p. 170, 171) who named it after Wolfpen Hill in the east-central part of the Narlborough quadrangle.

sgd

Salem Gabbro-Diorite, medium- to very dark-gray, weathering slightly darker with a brownish cast, very fine- to medium-grained, equagranular seriate or porphyritic texture, non foliated to moderately foliated rock ranging from quartz diorite to gabbro in composition. The grain size, texture and composition is commonly quite variable. Mafic minerals compose 10 to 40 percent of rock with both hornblende and biotite present. Mafic minerals are chloritized locally. Minor amount of magnetite is present and the unit causes aeromagnetic highs. The seriate and porphyritic varieties have feldspar phenocrysts, altered pink locally, ranging from $.5 \mathrm{~mm}$ to $2 \mathrm{~cm}$. The groundmass may be slightly schistose locally. Much of the foliation could be primary flow foliation. 
The Salem in the type area around Salem, Massachusetts, has a radiometric age of about 450 my \pm 10, (Zartman, person. commun.), Late Middle Ordovician, but geologic field relations suggests a younger, perhaps Devonian age (Dennen, 1976, p. 271).

mg

Milford Granite, light-gray to light pinkish gray, weathering about the same or slightly lighter, fine- to medium-grained, equagranular to porphyritic rock that varies in composition from granite to granodiorite. Biotite is locally present; but generally the mafic minerals are altered to chlorite. In the lighter-colored varieties only minor chlorite, accompanied by some sericite, is present. Much of the rock is only slightly foliated and altered to produce pink feldspar and chloritized mafic minerals as at the interchange on Interstate Route 495 and Route 9. The rock is more foliated and altered in the southeast portion of the quadrangle where much of the rock appears bleached. The foliation there, is highly variable changing from very slight to strongly foliated over a distance of a meter or less. The grain size has been greatly reduced in the strongly foliated part and the intrusive becomes similar in appearance to the xenoliths of quartzite which are common. The foliation parallels the bedding in the xenoliths. The rock contains numerous scattered xenoliths of very light-gray quartzite and dark greenish gray chloritic granular schist of the 
Westboro Formation. The rock is generally well jointed with the most prominent joints parallel to the foliation. Samples of : the Milford Granite from the Milford Quadrangle, Massachusetts, yielded a $620 \pm 15 \mathrm{my}$, Precambrian, zircon age according to Richard Naylor (personal commun.) (Nelson, 1975).

\section{$\mathbf{f g}$}

Foliated Granite, light- to medium-gray, weathering the same to slightly darker, medium-grained, equigranular to slightly porphyritic foliated rock approximately quartz monzonite to granodiorite in composition. Contains 10 to 20 percent mafic minerals with biotite dominant. The rock is highly variable in degree of foliation and appearance. It grades into rock like the Milford Granite and appears to be a slightly more mafic border phase of the Milford. The unit intrudes the Westboro Formation and contains xenoliths of quartzite and dark greenish gray granular schist of the Westboro Formation. The foliated granite is interpreted to be mixed with the Westboro Formation beneath covers in the southwestern part of the quadrangle from exposures further southwest. 


$$
q m-g d
$$

Quartz Monzonite - Granodiorite, light-gray, light pinkish gray, weathering same to slightly darker, medium-grained, equagranular to slightly porphyritic rock, approximately quartz monzonite to granodiorite in composition, slightly to moderately foliated; strongly foliated locally. Minor mafic minerals present which are generally chloritized. Xenoliths of light gray quartzite and dark greenish gray chloritic granular schist are commonly present. Much of the rock is altered with pink feldspar and/very similar to the part of the Milford granite with similar alteration, except that it is generally more strongly foliated. The degree of foliation varies, but the rock does not appear to have the closely spaced alternations in degree of foliation that is present in the Milford in the southeast portion of the quadrangle. The rock is very similar to the Milford granite and is probably part of it, but was kept separate because of minor differences in appearance. The foliated granite probably grades into this unit. 


\section{fqd}

Foliated Biotite Quartz Diorite, medium-gray, weathering slightly lighter with a brownish cast, medium-grained, equagranular moderately foliated rock approximately biotite quartz diorite in composition. Mafic minerals compose 25 to 30 percent of the rock and consist predominately of small clots of finely divided biotite flakes. The feldspar locally has a greenish cast and appears saussuritized. Relative age and relations with other rocks are not clear, but locally it is more foliated than the adjacent quartz monzonite-granodiorite rock and may possibly be slightly older than it.

\section{Metasedimentary and_Metavolcanic Rocks}

nu

Nashoba Formation, consists of light-to dark-gray rocks in relatively homogeneous members composed chiefly of medium-grained muscovite biotite-oligoclase-quartz geneiss alternating with members of more heterogeneous lithology including fine-grained amphibole-biotite gneiss and schist, amphibolite, mica schist locally sulfidic, calcsilicate-bearing gneiss and a few lenses of marble. The formation is used here as originally defined by Hansen (1956) to include all the stratified rocks between the Marlboro Formation and the Tadmuck Brook Schist. The formation has subsequently been restricted (Bell 
and Alvord, 1976) by separating the distinctive Fishbrook Gneiss and underlying Shawsheen Gneiss from its base. Alvord (1975) also divided the restricted Nashoba into 10 members. Only those members known to occur in the Marlboro Quadrangle anescribed below. The Nashoba Formation is intruded by the Andover Granite and Assabet Quartz Diorite. The formation is in fault contact to the northeast with the Newbury Volcanics, a sequence of essentially unmetamorphosed volcanogenic rocks containing Late Silurian or Early Devonian fossils (Shride, 1976): The Nashoba is thus Early Paleozoic or possibly Precambrian in age. The Nashoba has a maximum thickness of 15,010 $\mathrm{m}$ (Be11 and Alvord, 1976).

$n E$

'ort Pond Member, consists of varied lithology; the lower part is made up mostly of medium- to dark-gray fine-grained amphibole-biotite gneiss, calc-silicate (diopside-tremolite) bearing gneiss or fels, and amphibolite. The upper part consists chiefly of the same rock as the lower part but includes in addition, some sulfidic sillimanite-mica schist and discontinuous beds of marble. The upper contact with the Long Pond Gneiss Member is believed to be conformable, but at many localities the contact is faulted (D. C. Alvord, person. commun.). The member has a maximum thickriess of $1,470 \mathrm{~m}$. (Bell and Alvord, 1976). 
nn

Nagog Pond Gneiss Member, chiefly 1ight- to medium-gray, mediumgrained muscovite-biotite-oligoclase-quartz gneiss, that characterizes the Nashoba Formation, interstratified with some amphibole-biotite gneiss and lenticular bodies of thinly bedded amphibolite and massive amphibolite. The upper contact is concealed, but is considered conformable (D. C. Alvord, persion. commun.). The maximum thickness of the member is $1,370 \mathrm{~m}$ (Bell and Alvord, 1976).

nnb

Nashoha Brook Member, heterogeneous assortment of medium- to darkgray amphibole-biotite gneiss, medium greenish gray diopsidic calcsilicate bearing gneiss and fels with dark-gray amphibolite in the upper and lower parts. The middle part is chiefly sulfidic sillimanite-biotite-muscovite schist and gneiss with subordinate amounts of amphibolite and biotite gneiss. The upper contact is conformable and gradational (D. C. Alvord, person. commun.). Its maximum thickness if $920 \mathrm{~m}$ (Bell and Alvord, 1976). 
Shawsheen. Gneiss, consists of 1ight-to medium-gray medium-grained locally sillimantic muscovite-biotite-oligoclase-quartz gneiss with some lenticular bodies of bedded and massive amphibolite. Sulfidic sillimanite-mica schist is present near the base. The Principal rock type is identical to the most comnon rock type in the Nashoba Formation, but Be1l and Alvord (1976) have separated the formation from the Nashoba by the Fish Brook Gneiss. The upper contact of the Shawsheen is conformable with the Fish Brook. The Shawsheen has a maximum thickness of $2,600 \mathrm{~m}$ (Bell and Alvord, 1976).

$\mathbf{m}$

Harlboro Formation, upper part is chiefly dark-gray to nearly black thinly layered fine-grained amphibolite interlayered with massive medium to coarse-grained amphibolite and minor amounts of other rock types. This is separated as the Sandy Pond Member to the northeast (Be11 and Alvord, 1976). The lower part consists of similar rocks that are much more thickly bedded; mainly in medium to thick beds. The area of the Formation also includes some small bodies of intrusive quartz diorite.

The base of the Marlboro is faulted. The top is conformable and gradational into the Shawsheen Gneiss. The contact is placed where muscovite-biotite gneiss and schist greatly exceeds amphibolite. 
The Marlboro has a maximum thickness of $2,140 \mathrm{~m}$ in the Shrewsbury quadrangle (Be1l and Alvord, 1976).

Westboro Formation, light-gray to buff, veathering about the same, commonly laminated, well bedded thin to thick bedded quartzite; dark greenish gray, weathering about the same to slightly lighter, mainly medium-bedded chloritic granular schist becoming biotitic locally; and a minor amount of light greenish gray and light purplish gray, weathering about the same, thin bedded metasiltstone. These rocks are interbedded with the quartzite forming a little less than half of the main outcrop band and occurring mainly in the lower half. Quartzite forms the bulk of the scattered pendents and xenoliths of the Westboro in the surrounding intrusive rocks. The Westboro Quartzite was named by Emerson (1917) for exposures around Westboro in the southwest part of the quadranble, but would better be referred to as a formation due to the large amount of granular schist in the unit. The Nestboro is the oldest unit known in the quadrangle and may be considered Precambrian as it is intruded by the Milford Granite dated as Precambrian. Areas shown as Westboro contain large amounts of foliated intrusive rock locally. 
Marlborough Quadrangle, Barosh

\section{References}

Alvord, D.C., 1975, Preliminary bedrock geologic maps of the Westford and Billerica quadrangles, Middlesex County, Massachusetts:

U.S. Geol. Survey open-file report $75-387,12$ p., scale 1:24,000. Bell, K.G., and Alvord, D.C., 1976, Pre-Silurian stratigraphy of northeastern Massachusetts, in Page, L.R., ed., Contributions to the stratigraphy of New England: Geol. Soc. America Mem. 148, P. 149-216.

Dennen, W.H., 1976, Plutonic series in the Cape Ann area, in New England Intercollegiate Geol. Conf. 68th Ann. Mtg., Boston, Mass., Oct. 8-10, 1976, Geology of southeastern New England; a guidebook for field trips to the Boston area and vicinity; Princeton, N.J., Science Press, p. 265-278.

Emerson, B.K., 1917, Geology of Nassachusetts and Rhode Island: U.S. Geol. Survey Bull. 597, 289 p., scale 1:250,000.

Hansen, W.R., 1956, Geology and mineral resources of the Hudson and Maynard quadrangle, Massachusetts: U.S. Geol. Survey Bull. 1038, $104 \mathrm{p}$.

Lacroix, A.V., 1968, Structure and contact relationships of the Marlboro Formation, Marlboro, Massachusetts: Boston College, unpub. MS thesis, 83 p. Nịlson, A.E., 1975, Bedrock geologic map of the Framingham quadrangle, Middlesex and Worcester Counties, Massachusetts: U.S. Geol. Survey Quad. Map GQ-1208, scale 1:24,000. 
Shride, A.F., 1976, Stratigraphy and correlation of the Newbury

Volcanic Complex, northeastern Massachusetts, in Page, L.R., ed., Contributions to the stratigraphy of New England: Geol. Soc. America Mem. 148, p. 147-148.

Skehain, J.W., 1964, Folio of maps and cross sections of the WachusettMarlborough tunnel, Clinton to Marlborough, Massachusetts:

Boston, unpub. rept. for Metropolitan District Commission, 42 maps and sections, scale 1:2400. 
Marlborough Quadrangle, Barosh

\section{Correlation of Map Units}

\section{Metasedimentary and}

Igneous Rocks

\section{Metavolcanic rocks}
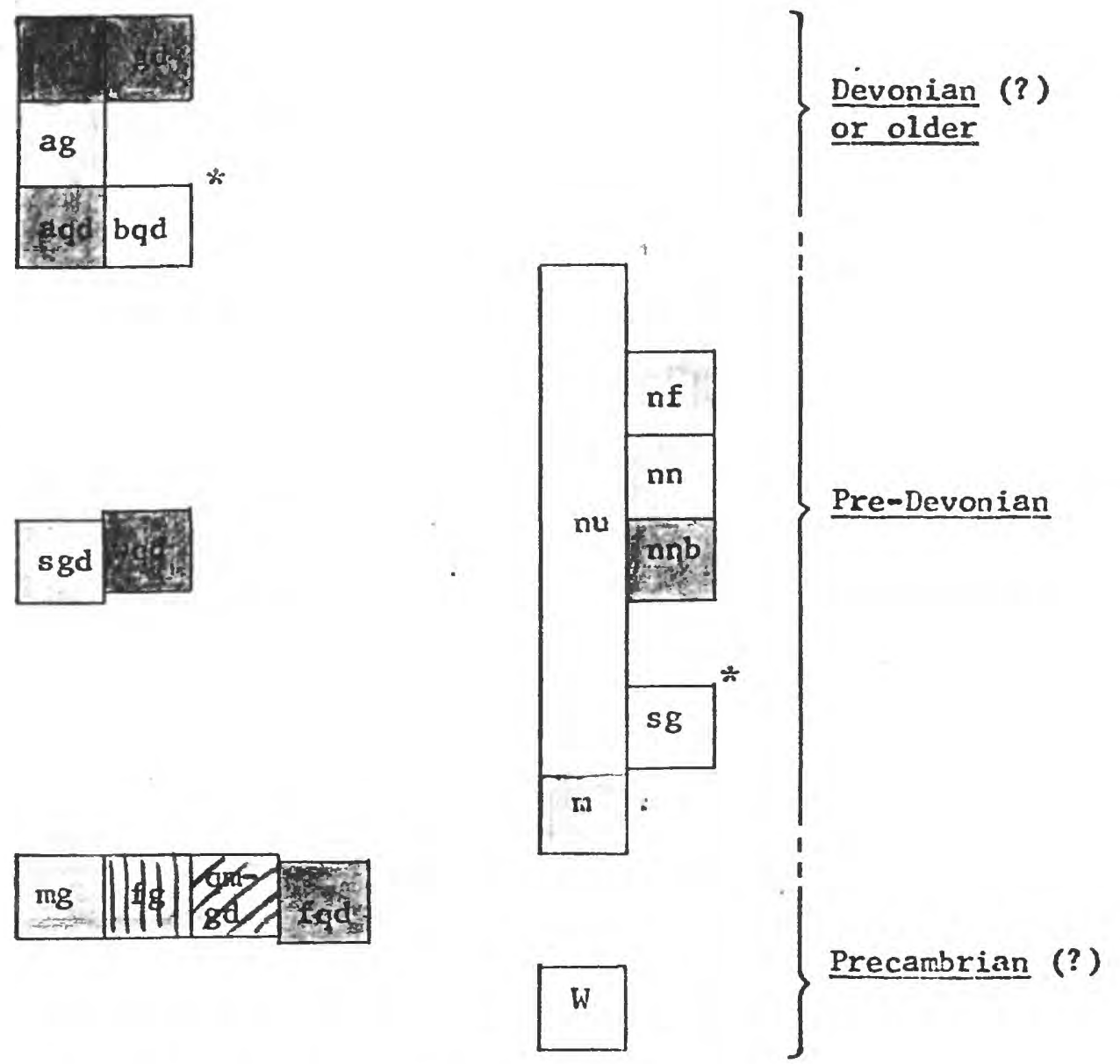

* not shown separately on map 


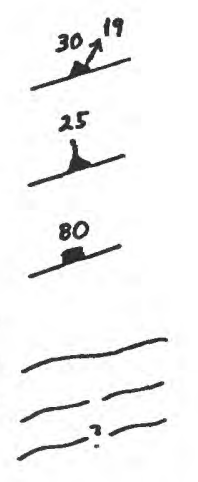

foliation and lineation, indicated by arrow

foliation and bedding

joint

contact, dashed where approximate, querried wirere probable

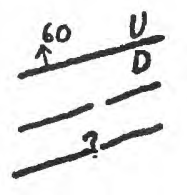

fault, showing dip and relative movement: $U$, up; $D$, down; dashed where approximate, querried where probable

\section{topographic lineament}

fr

anticlinal axis, showing direction of plunge 